\title{
Integrating Cost-231 Multiwall Propagation and Adaptive Data Rate Method for Access Point Placement Recommendation
}

\author{
Fransiska Sisilia Mukti ${ }^{1}$, Puput Dani Prasetyo Adi $^{2 *(i)}$, Dwi Arman Prasetya ${ }^{3}$ \\ Volvo Sihombing ${ }^{4}$, Nicodemus Rahanra ${ }^{5}$, Kristia Yuliawan ${ }^{6}$, Julianto Simatupang ${ }^{7}$ \\ Department of Informatic, Technology and Design Faculty, Institut Teknologi dan Bisnis Asia Malang, Indonesia ${ }^{1}$ \\ Department of Electrical Engineering, Engineering Faculty, University of Merdeka Malang ${ }^{2,3}$ \\ Department of Informatics Management, Faculty of Science and Technology, Universitas Labuhanbatu ${ }^{4}$ \\ Department of Informatics Engineering, Faculty of technology and Engineering, Universitas Satya Wiyata Mandala ${ }^{5}$ \\ Department of Informatics Engineering, Engineering Faculty, Universitas Negeri Papua ${ }^{6}$ \\ Department of Information Technology, AMIK Mahaputra, Riau ${ }^{7}$
}

\begin{abstract}
A new approach has been developed to provide an overview about signal behavior in indoor environments using Cost-231 Multiwall Model (Cost-231 MWM) and Adaptive Data Rate (ADR) method. This approach used as a reference for access point (AP) placement for campus building. The Cost-231 MWM plays a role in estimating the measured power received by user (usually called as Received Signal Strength Indicator/RSSI) by considering the existence of obstacles around the transmitter (AP). We used Institut Asia Malang environments as the case study and gave some recommendations for AP placement: ten optimal placements for the first, third and fourth floor, also seven optimal placements for the second floor. These recommendations were based on the RSSI for good and excellent level signal $(-50 \mathrm{dBm}$ until $-10 \mathrm{dBm})$. This research also uses the Adaptive Data Rate (ADR) mechanism approach to reduce the amount of packet loss (kbps) resulting from obstacles that cause attenuation (-dB). With the Adaptive Data Rate mechanism, it means increasing the number of access points, the signal attenuation (-dB) occurs from the obstacles (Walls) that are penetrated by the Radio Frequency device and causes attenuation (-dB), the more Access points on the Multi-Wall, will allow communication and data transmitting stability.
\end{abstract}

Keywords-Access point placement; indoor propagation; Cost231 Multiwall; ADR; RSSI

\section{INTRODUCTION}

Recently, wireless network technology is not something foreign to society but has become one of the main communication media infrastructures over time. Refers to the IEEE 802.11, wireless network has been developing rapidly [1], [14],[18]. This technology uses electromagnetic waves for communication between nodes. Flexibility and mobility were the main points why this technology is in great demand by users than cable line [2]. For the local area, we usually named this technology as Wireless Local Area Network (WLAN). WLAN is becoming familiar wireless technology built as an extension of a wired LAN [3], [24].

Even though it provides convenience in the installation and configuration process, building a wireless network cannot be underestimated. A network engineer must understand the environments clearly about the interferences that may occur on-site, especially for indoor environments. This factor makes the placement of wireless transmitter devices (named as Access Point or AP) quite tricky to do because misplacement of AP will cause decreasing in communication performance.

Specifically, understanding the propagation of a signal from transmitter to receiver in wireless communication is studied in propagation. Indoor and outdoor propagation have different parameters; even indoor propagation provides more complicated parameters than outdoor propagation [4]. This is due to the presence of the materials around the APs could attenuate the signal while transmitted to the user [2], such as reflection, diffraction, or scattering [5], [11], [13], [16].

Studies were conducted to find out the best approach for indoor propagation, [6] both mathematical equations and based on site-survey measurement. Some new models were also developed to evaluate the signal's behaviors for various environments. Different propagation models also presented the effects of building layout and found the best approach for the environment. [7] Statistical models have been considered as an excellent strategy in designing wireless infrastructure without the need for detailed analysis indeed.

Several studies were deployed to evaluate the accuracy of empirical propagation for the indoor environment. the Cost231 Multiwall propagation model and the Offered Bit Quantity method to determine the optimal number of APs and the placement. The results show that this method provides a better coverage area, and a more substantial signal strength value reaches $-27.27 \mathrm{dBm}$ [8]. An APs placement design must consider the importance of propagation losses. The calculation used empirical propagation based on the areas [9]. Mukti was compared four types of propagation : one slope, log-distance, cost-231 MWM and ITU-R, to figure out which the most suitable modelling for campus environment. For that case, ITU-R (P.1238) model gave the closest results to actual measurement with $16,381 \%$ relative error rate [5].

As one of the educational institution, Institut Asia Malang used WLAN as its wireless infrastructure. This place consists

*Corresponding Author 
of four floors where each floor has several APs. Previous research [6] showed that there are still several locations categorized as blank spots (with the poor signal level of 0$39 \%$ ) because AP placement is only based on the officer's feeling, without considering the aspect of propagation. Based on this case, this study aims to bring an idea in AP's placement using Cost-231 Multiwall Model (MWM) as one of the empirical propagation models and integrate it with adaptive rate method for improving the received signal level for the users. This approach will take a concern about environmental interferences such as floors, walls, doors, etc. The results will be used as a recommendation for the related part of the institution.

\section{THEORY}

\section{A. COST-231 Multi-Wall Model}

Cost-231 MWM gives better accuracy than the earlier model such One Slope Model (1SM), because it used environment description as the input variable [3]. Overview about this model shown in Figure 1, while the pathloss value between transmitter and receiver calculated using Equation1.

$L_{M W}=L_{F S L}(d)+\sum(N, i=1) k_{w i} L_{w i}+k_{f} L_{f}$

It is important to pay attention of the parameters such as wall attenuation, to get the closest prediction. $L_{w i}$ does not represent actual value, but only a statistical value from representative calculations in previous studies. There are two types of wall in Cost-231 MWM: light wall (L1) with thin wall or partitions, and heavy walls (L2) as thick structured walls. Meanwhile, other parameters was defined in Table 1 and Table 2 [3][7].

\section{B. Free Space Path Loss (FSPL)}

FSPL defined as losses of RF signal while reaching certain distance (between transmitter and receiver antenna). Equation 2 specifically gives mathematical equation to find this value [3][5].

$$
L_{F S L}(d)=32,44+20 \log (d)+20 \log (f)
$$

where $L_{F S L}$ as free space loss value in $\mathrm{dB}, d$ refers to TX and RX distance in meters and $f$ as AP's frequency in $\mathrm{MHz}$.

\section{Received Signal Strength Indicator (RSSI)}

In telecommunications, received signal strength indicator (RSSI) is a measurement of the power present in a received radio signal. A well-managed wireless network can provide a good RSSI value (a negative value is said to be $0 \mathrm{~dB}$ ) [4][3][5][28]. The RSSI value is obtained from Equation 3.

$R S S I=E I R P-F_{S L}+G_{R}-L_{M W}$

where $R S S I$ inform the received signal by user in $\mathrm{dB}, E I R P$ as the power of AP when transmit data in $\mathrm{dBm}, G_{R}$ as $\mathrm{RX}$ gain in $\mathrm{dBm}$ and $L_{M W}$ as the pathloss value calculation using Cost231 MWM.

\section{Effective Isotropic Radiated Power (EIRP)}

EIRP is the total energy expended by an access point and antenna. When an access point sends its energy to the antenna to be transmitted, a large reduction in energy will occur in the cable. To compensate for this, an antenna adds power / gain, the amount of additional power will depend on the type of antenna used [10]. Equation 4 represent the calculation of this value.

$E I R P=P_{T}+G_{R}-L_{M W}$

where $P_{T}$ as the transmit power of the device in $\mathrm{dBm}$.

\section{E. Data Rate and Sensitivity}

Data rate also determined as spreading factor, are influenced by the distance between TX and RX. The farther the distance, the weaker the signal strength. It will affects the throughput of the communication. The throughput is getting smaller and the packet loss is getting bigger. And the greater the value of the spreading factor, the longer it takes the transmitter to reach the receivers or Time on Air (ms) [11], [22], [24].

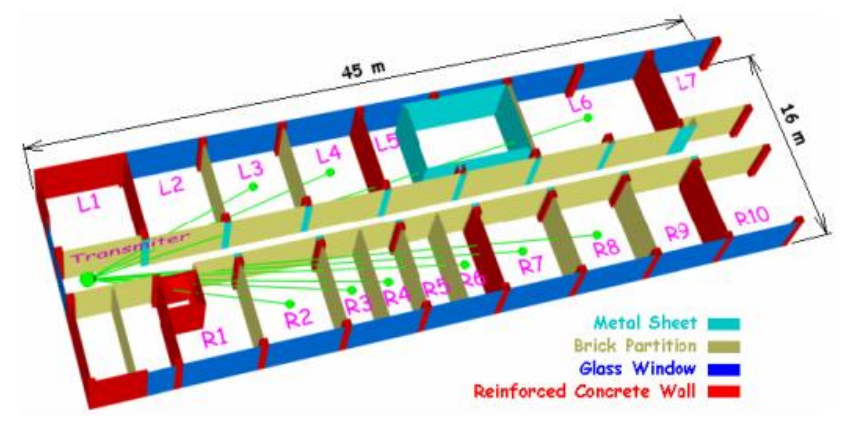

Fig. 1. Geometries Multi-Wall Model.

TABLE I. ATtENUATION VALUE OF RADIO FREQUENCY ON THE INDOOR BUILDING MATERIALS

\begin{tabular}{|l|l|l|}
\hline Nu. & Parameter & Attenuation Value (dB) \\
\hline 1. & Cubicle wall & 2 \\
\hline 2. & Wooden door & 3 \\
\hline 3. & Glass window & 3 \\
\hline 4. & Drywall or sheetrock & 3 \\
\hline 5. & Metal shelf & 6 \\
\hline 6. & Elevator or metal particles & 10 \\
\hline 7. & Brick, concrete, concrete block & 12 \\
\hline 8. & Ceramic Floor & 13.2 \\
\hline 9. & Foundation wall & 15 \\
\hline
\end{tabular}

TABLE II. Signal Attenuation Value at $2.4 \mathrm{GHz}$ Frequency

\begin{tabular}{|l|l|l|}
\hline Nu. & Parameter & Attenuation Value (dB) \\
\hline 1. & Brick wall window & 2 \\
\hline 2. & Brick wall next to metal door & 3 \\
\hline 3. & Cinder block wall & 4 \\
\hline 4. & Office walls & 6 \\
\hline 5. & Office wall metal doors & 6 \\
\hline 6. & Metal glass wall frame & 6 \\
\hline 7. & Metal door on brick wall & 12.4 \\
\hline
\end{tabular}


TABLE III. DATA RATE, SENSITIVITY AND TIME ON AiR

\begin{tabular}{|l|l|l|}
\hline Data Rate (Spreading Factor) & Time on Air & Sensitivity \\
\hline SF7 & $41 \mathrm{~ms}$ & $-123 \mathrm{dBm}$ \\
\hline SF8 & $72 \mathrm{~ms}$ & $-126 \mathrm{dBm}$ \\
\hline SF9 & $144 \mathrm{~ms}$ & $-129 \mathrm{dBm}$ \\
\hline SF10 & $288 \mathrm{~ms}$ & $-132 \mathrm{dBm}$ \\
\hline SF11 & $577 \mathrm{~ms}$ & $-134.5 \mathrm{dBm}$ \\
\hline SF12 & $991 \mathrm{~ms}$ & $-137 \mathrm{dBm}$ \\
\hline
\end{tabular}

\section{METHOD USED}

\section{A. Real Measurement and Analyze use inSSIDer}

This research is a continuation from some previous studies [3][6]. Located in Institut Asia Malang, this research used the site survey measurements which calculated repeatedly using regression method and inSSIDER application to get real the signal strength values. The measurement was built in two propagation paths: Line of Sight (LoS) path and Non Line of Sight (NLoS) path. More than 25 measurement points were taken for each floor in order to get the best accuration on sampling (close to $90 \%$ ).

To find out the closest RSSI level prediction compared to the real values from site survey measurements before, we evaluated all propagation parameters and calculated it into Equation 1 to 4 with detail specifications below (Tabel IV) [3].

We analyzed every points and elected the optimal placement based on best RSSI level, both on LoS and NLoS path, for excellent signal level (see table V) [21],[25],[26],[27].

\section{B. Adaptive Data Rate (ADR) Mechanism Approach}

Adaptive Data Rate (ADR) [12],[16] is a mechanism for increasing the number of receivers or access points at a certain point which aims to amplify the signal transmitted by the transmitter (Tx) in an internet network [19]. The additional AP is then sent to another AP in a condition that it is blocked by a wall of different thickness, type, and wall material. This affects the state of the signal resulting in an attenuation signal [17], [22].

Therefore, the function of the Additional AP is to strengthen signal reception in receivers or EDs and reduce packet loss or increase throughput [20]. Figure 2 is an example of ADR representation to make it easier to understand Adaptive Data Rate Mechanism on Multi Wall.

The Adaptive Data Rate Schedule mechanism in Figure 3 consists of three critical parameters, i.e., Uplink, Downlink, and ADR Response. In the Uplink Process, the ADR must be determined the data bits will be sent; therefore, they are recorded in the uplink data process using the ADR Ack bit. Some ADR parameters originating from the downlink, i.e., ADR scheduled, ADR failed, Collected data, and ADR is running. The last thing is about ADR Response, if successful then ADR Success, and go to the un-schedule ADR process. The ADR algorithm is often used for Low Data Rate data such as that of LoRa and together with Spreading Factor analysis (612) $[15],][20],[23]$.
TABLE IV. PROPAGATION PARAMETER SPECIFICATIONS

\begin{tabular}{|l|l|l|}
\hline Nu. & Parameter & Value \\
\hline 1. & Operating band (frequency $/ f$ ) & $2.4 \mathrm{GHz}$ \\
\hline 2. & TX gain & $3 \mathrm{dBi}$ \\
\hline 3. & RX gain $\left(\mathrm{G}_{\mathrm{R}}\right)$ & $0 \mathrm{dBi}$ \\
\hline 4. & Maximum TX Power & $27 \mathrm{dBm}$ \\
\hline 5. & Line losses & $0.5 \mathrm{~dB}$ \\
\hline 6. & Fading margin of WLAN & $10 \mathrm{~dB}$ \\
\hline
\end{tabular}

TABLE V. RSSI CATEGORY FOR WLAN

\begin{tabular}{|l|l|l|}
\hline Category & Range $(\mathbf{d B m})$ & Percentage $(\boldsymbol{\%})$ \\
\hline Excellent & -57 to -10 & $75-100$ \\
\hline Good & -75 to -58 & $40-74$ \\
\hline Fair & -85 to -76 & $20-39$ \\
\hline Poor & -95 to -86 & $0-19$ \\
\hline
\end{tabular}

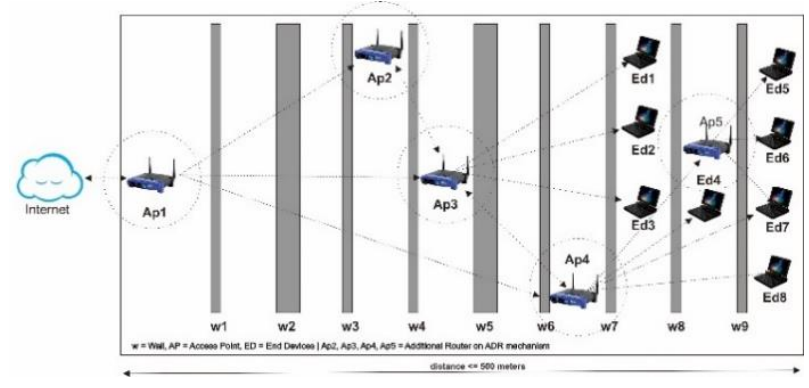

Fig. 2. Adaptive Data Rate Mechanism on Multi Wall.

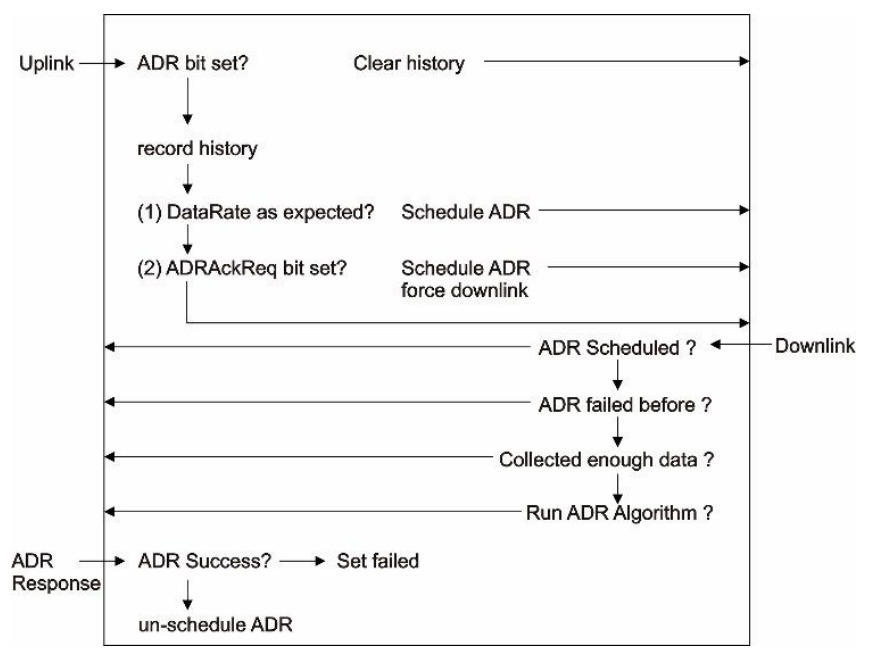

Fig. 3. Adaptive Data Rate Schedule Mechanism.

\section{RESUlT AND DisCUSSION}

The analysis started with evaluating the building structure for each floor. First floor showed more free space area, while the second, third and fourth floor seemed to be closed building with some rooms and corridors. We made some prediction location for AP placement and adopted 12 measurement points in first floor, both indoor and outdoor placement. We also defined every obstacle around the APs so that we can calculating the values, as shown in Figure 4. 


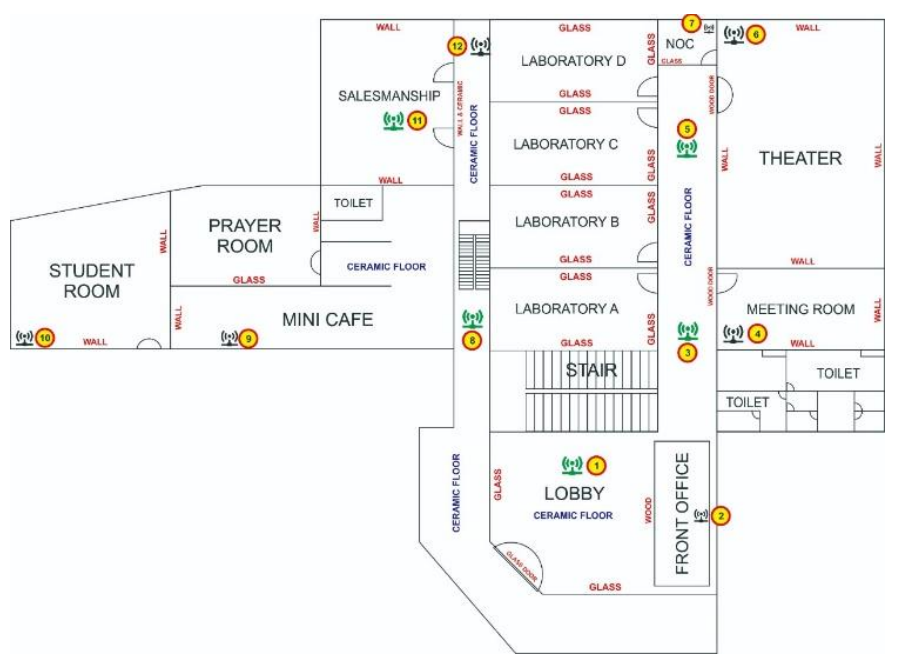

Fig. 4. Floor Plan 1 along with Obstacle Description.

Because every obstacle has their own attenuation values (see Table II and Table III), we must identify it exactly, to avoid miscalculated prediction. These identification process will be used to find the pathloss and EIRP value for every placement point using Cost-231 MWM and ADR method. The sample results shown at Table VI. Propagation theory for closed room claimed that the best transmitted signal occurred while in LoS propagation (there are no barrier between AP and user) [6], [11], [12]. We could see the LoS path for the first floor are placement on number 1, 3, 5, 8, 9 and 12. The best signal coverage is reached for indoor only, while the outdoor area (NLoS path) could not capture the signal properly. Based on these calculations, we took only $-58 \mathrm{dBm}$ to $-10 \mathrm{dBm}$ values for recommendation placements (defined as excellent and good signal levels, see Table V). Therefore, we recommend number 1 until 10 as the placement points.

TABLE VI. EIRP CALCULATION For AP PLACEMENT POINT SAMPLES ON $1^{\mathrm{ST}}$ FLOOR

\begin{tabular}{|c|c|c|c|}
\hline \multirow{2}{*}{ AP } & \multicolumn{2}{|l|}{ Obstacles } & \multirow{2}{*}{$\operatorname{EIRP}(d B)$} \\
\hline & Type & Attenuation dB) & \\
\hline 1 & $\begin{array}{l}\text { Ceramic Floor } \\
\text { Glass } \\
\text { Glass door } \\
\text { Wood Dividers }\end{array}$ & $\begin{array}{l}13.2 \\
3 \\
6 \\
3 \\
\end{array}$ & 4.8 \\
\hline 2 & $\begin{array}{l}\text { Wall } \\
\text { Wood cupboard } \\
\text { Glass window }\end{array}$ & $\begin{array}{l}6 \\
3 \\
3\end{array}$ & 12 \\
\hline 3 & $\begin{array}{l}\text { Wooden door } \\
\text { Glass } \\
\text { Ceramic Floor } \\
\text { Wooden partition }\end{array}$ & $\begin{array}{l}3 \\
3 \\
13.2 \\
3\end{array}$ & 1.8 \\
\hline 4 & $\begin{array}{l}\text { Wooden door } \\
\text { Wall } \\
\text { Glass table } \\
\text { Ceramic Floor }\end{array}$ & $\begin{array}{l}3 \\
6 \\
6 \\
13.2\end{array}$ & 1.8 \\
\hline 5 & $\begin{array}{l}\text { Ceramic Floor } \\
\text { Glass } \\
\text { Metal frame } \\
\text { Wooden door } \\
\text { Wall }\end{array}$ & $\begin{array}{l}13.2 \\
3 \\
6 \\
3 \\
6\end{array}$ & -1.2 \\
\hline
\end{tabular}

The same process was carried out for second, third and fourth floors. Even though all of them have the same building structure, however, we still carry out an in-depth analysis for each floor and found 7 optimal placements for second floor, 10 optimal placements for third floor and 9 optimal placements for fourth floor. Furthermore, we figured out the RSSI values prediction for each placement and compared it with our previous studies (site-survey measurements and One Slope Model). In order to obtain the accuracy validity of the comparison, we used the same test point.

In order to get an overview of the comparison of the proposed methods, we visualize the results of our observations through Figure 5-8. For the first floor, we used placement point number 12 and calculated the RSSI values for each approach (see Figure 5). Meanwhile in second floor, there is only one AP placed in center of the corridor, and the results showed on Figure 6.

$3^{\text {rd }}$ floor became most crowded place because this place consists of 9 classrooms and lecturer's room. Almost all of the lecture activities are carried out in this area. Two AP are placed in this area: center of the corridor and in the lecture room. We compared the results into a graph on Figure 7. Hereafter, we got some calculation also for the fourth floor, and showed the analysis into a graph on Figure 8.

\section{Power Level Comparison (-dBm) with ADR Approach on 1st floor}

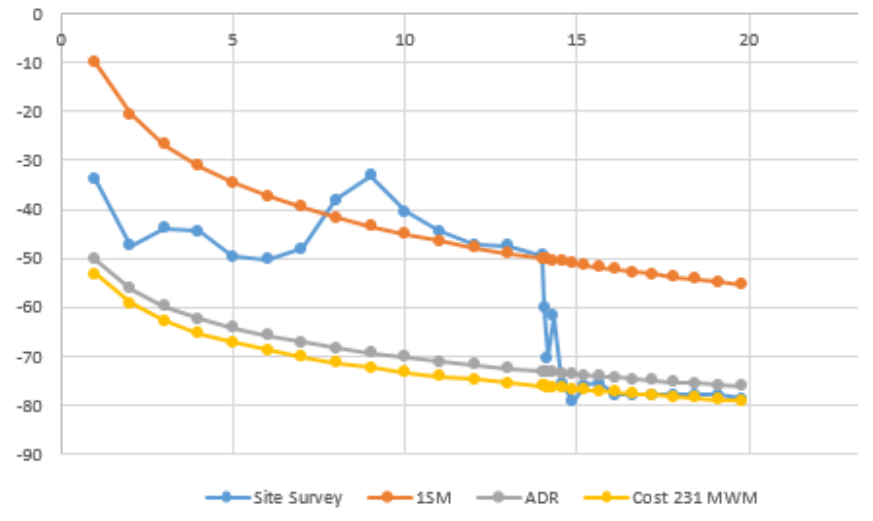

Fig. 5. Power Level Comparison on $1^{\text {st }}$ Floor.

Power Level Comparison (-dBm) with ADR Approach on 2nd floor

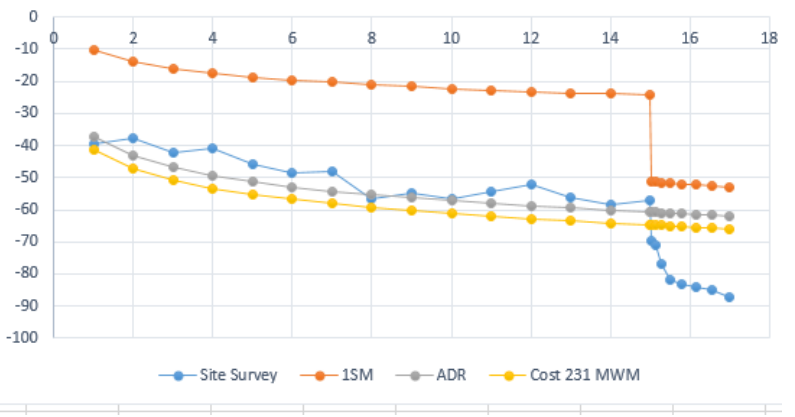

Fig. 6. Power Level Comparison on $2^{\text {nd }}$ Floor. 
Power Level Comparison (-dBm) with ADR Approach on 3rd floor

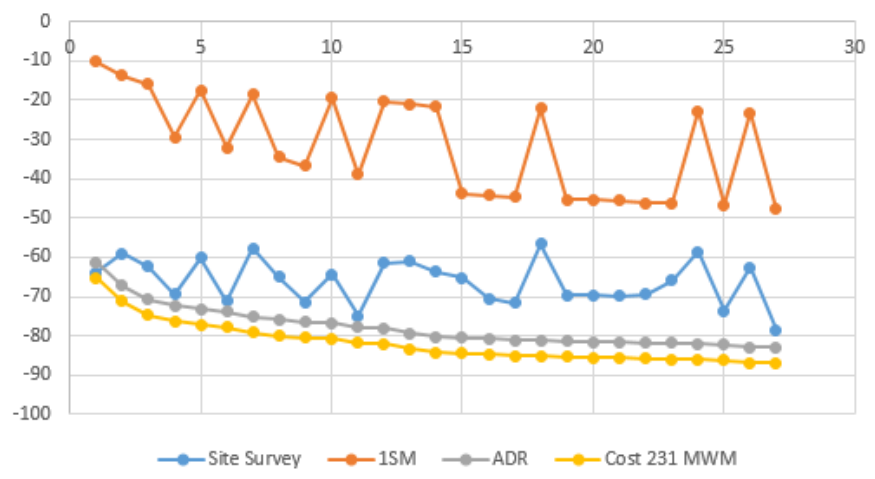

Fig. 7. Power Level Comparison on $3^{\text {rd }}$ Floor.

\section{Power Level Comparison (-dBm) with ADR Approach on 4th floor}

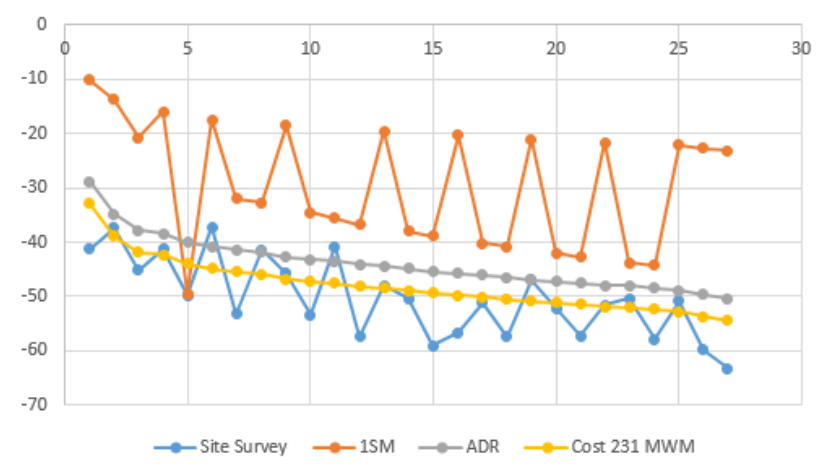

Fig. 8. Power Level Comparison on $4^{\text {th }}$ Floor.

The comparison of power levels shown in Figure 5 to Figure 8 shows that Cost-231 MWM and ADR method give closest value than One Slope Mode on previous studies. It proves that our approach can be used as RSSI prediction method for indoor environments, because we considered the existence of the obstacles which has significant effect for the RSSI level. Therefore, it is essential to pay attention for AP placement.

\section{CONCLUSIONS}

Our research was built to find the closest prediction in RSSI level for indoor environments. It is greatly influenced by the existence of the obstacles between AP and user. The Cost231 MWM approach provides a closest propagation values which compared with actual values based on site-survey measurement. Our analysis proved that the obstacle gives significant impact for the user's signal level (RSSI). Signal strength analysis was performed on the LOS and NLOS propagation paths. We showed there were 10 optimal placements for first, third and fourth floor, also 7 optimal placements for second floor. These recommendation was choose based on signal strength susceptibility on $-58 \mathrm{dBm}$ to $10 \mathrm{dBm}$ for LoS propagation.
Our approach can be used as reference for the related division on Institut Asia Malang in reviewing the current AP placement. The objective of this research to provide a better area coverage and WLAN performance for case study. Further, the ADR method helps stabilize data from the transmitter and reduces data loss due to the large number of walls which results in attenuation of the signal from the transmitter and reduces the load on the Access point (APs).

\section{A. Future Work}

The analysis will be improved by increasing the number of APs using ADR methods and measuring the multistoried buildings and analyzing the signal measurement between multi-storey buildings and the number of houses in one area. Devices will be developed not only using WiFi, however, a combination of WSNs and LPWAN devices e.g., LoRaWAN and additional analysis using software and hardware to analyze signal strength or Radio Frequency in realtime. And as the additional analyzes is a Spreading Factor analyzes on the measurement. Also, this research can be developed into a desktop or android system which has ability to give an realtime overview for signal distribution.

\section{ACKNOWLEDGMENT}

Thanks to Institut Asia Malang, which has become a place for research and data collection so that this research can be completed properly, and thanks to the entire academic community of Institute Asia Malang, and University of Merdeka Malang (UNMER-Malang).

\section{REFERENCES}

[1] A. T. Suryani and A. B. Pantjawati, "Analysis of the Coverage Area of the Access Point Using Netspot Simulation," IOP Conf. Ser. Mater. Sci. Eng., vol. 384, no. 1, 2018, doi: 10.1088/1757-899X/384/1/012001.

[2] F. S. Mukti and A. Junikhah, "A Coverage Prediction Technique for Indoor Wireless Campus Network," J. INFOTEL, vol. 11, no. 3, pp. 7379, 2019, doi: 10.20895/infotel.v11i3.434.

[3] F. S. Mukti, "Access Point Placement Recommendation Using Cost-231 Multiwall Propagation," J. Penelit. Pos dan Inform., vol. 10, no. 2, p. 103, 2020, doi: 10.17933/jppi.2020.100202.

[4] F. S. Mukti and A. Junikhah, "Prediksi Cakupan Area untuk Jaringan Wireless Indoor Kampus berdasarkan Penempatan Access Point," J. Penelit. Ilmu Tek. dan Terap., vol. 10, no. 2, pp. 67-72, 2019, doi: https://doi.org/10.48056/jintake.v10i2.55.

[5] F. S. Mukti, "Studi Komparatif Empat Model Propagasi Empiris Dalam Ruangan untuk Jaringan Nirkabel Kampus," J. Teknol. dan Sist. Komput., vol. 7, no. 4, pp. 154-160, 2019, doi: 10.14710/jtsiskom.7.4.2019.154-160.

[6] F. S. Mukti and D. A. Sulistyo, "Analisis Penempatan Access Point Pada Jaringan Wireless Lan Stmik Asia Malang Menggunakan One Slope Model," J. Ilm. Teknol. Inf. Asia, vol. 13, no. 1, pp. 13-22, 2018, doi: 10.32815/jitika.v13i1.304.

[7] F. J. Carlos Vesga, H. Martha Fabiola Contreras, and B. Jose Antonio Vesga, "Design of empirical propagation models supported in the LogNormal Shadowing model for the $2.4 \mathrm{GHz}$ and $5 \mathrm{GHz}$ bands under Indoor environments," Indian J. Sci. Technol., vol. 11, no. 22, pp. 1-18, 2018, doi: 10.17485/ijst/2018/v11i22/122149.

[8] M. A. Amanaf, E. S. Nugraha, and L. Azhari, "Analisis Optimasi Perencanaan Ulang Access Point Wifi Dengan Model Pathloss COST 231 Multi Wall dan Metode Offered Bit Quantity (OBQ) Studi Kasus Gedung Telematika ITTP,” J. Telecommun. Electron. Control Eng., vol. 1, no. 01, pp. 32-42, 2019, doi: 10.20895/jtece.v1i01.39.

[9] P. Titahningsih, R. Primananda, and S. R. Akbar, "Perancangan Penempatan Access Point untuk Jaringan Wifi Pada Kereta Api 
Penumpang," J. Pengemb. Teknol. Inf. dan Ilmu Komput. Univ. Brawijaya, vol. 2, no. 5, pp. 2008-2015, 2018.

[10] A. Fauzi and M. Arrofiq, "Assesment Kekuatan Daya Received Signal Level (RSL) Wireless $2.4 \mathrm{GHz}$ di Ruang meeting," J. Internet Softw. Eng., vol. 1, no. 1, pp. 10-17, 2020.

[11] Adi, P.D.P, Kitagawa, "A performance of radio frequency and signal strength of LoRa with BME280 sensor", Telkomnika (Telecommunication Computing Electronics and Control),Issue 2, 1 April 2020, Pages 649-660, DOI: 10.12928/telkomnika.v18i2.14843.

[12] Kunho Park, Junhyun Park, Junhyun Park, A-Hyun Lee, Chong-kwon Kim, "An Energy Efficient ADR Mechanism Considering Collision Rate in LoRa Network", December 2020, KIISE Transactions on Computing Practices 26(12):535-540, DOI: 10.5626/KTCP.2020.26.12.535.

[13] Puput Dani Prasetyo Adi and Akio Kitagawa, "ZigBee Radio Frequency (RF) Performance on Raspberry Pi 3 for Internet of Things (IoT) based Blood Pressure Sensors Monitoring" International Journal of Advanced Computer Science and Applications(IJACSA), 10(5), 2019. http://dx.doi.org/10.14569/IJACSA.2019.0100504.

[14] Fabian Rincon, et.al., "On the Impact of WiFi on $2.4 \mathrm{GHz}$ Industrial IoT Networks", October 2018, Conference: 2018 IEEE International Conference on Industrial Internet (ICII), DOI: 10.1109/ICII.2018.00012.

[15] Norhane Benkahla, Hajer Tounsi, Ye-Qiong Song, Mounir Frikha, "Review and experimental evaluation of ADR enhancements for LoRaWAN networks", January 2021, Springer, Telecommunication Systems, DOI: 10.1007/s11235-020-00738-x.

[16] Puput Dani Prasetyo Adi and Akio Kitagawa, "Quality of Service and Power Consumption Optimization on the IEEE 802.15.4 Pulse Sensor Node based on Internet of Things" International Journal of Advanced Computer Science and Applications(IJACSA), 10(5), 2019. http://dx.doi.org/10.14569/IJACSA.2019.0100518.

[17] Derek Heeger, et.al, "Secure LoRa Firmware Update with Adaptive Data Rate Techniques", March 2021, Sensors 21(7):2384, DOI: $10.3390 / \mathrm{s} 21072384$.

[18] Aathmanesan T, "Design of Metamaterial Antenna for $2.4 \mathrm{GHz}$ WiFi Applications", August 2020Wireless Personal Communications 111(4), Springer, DOI: 10.1007/s11277-020-07324-z.

[19] Puput Dani Prasetyo Adi and Akio Kitagawa, "Performance Evaluation of E32 Long Range Radio Frequency $915 \mathrm{MHz}$ based on Internet of Things and Micro Sensors Data" International Journal of Advanced Computer Science and Applications(IJACSA), 10(11), 2019. DOI: 10.14569/IJACSA.2019.010110.
[20] Smangaliso Mnguni, "Performance Evaluation of Spreading Factors in LoRa Networks", In book: Towards new e-Infrastructure and e-Services for Developing Countries, 12th EAI International Conference, AFRICOMM 2020, Ebène City, Mauritius, December 2-4, 2020, Proceedings, DOI:10.1007/978-3-030-70572-5_13.

[21] Stancu Eugen, et.al, "Spectral Analysis in the $2.4 \mathrm{GHz}$ WiFi Band in Bucharest", June 2020, Conference: 2020 13th International Conference on Communications (COMM), DOI: 10.1109/COMM48946.2020.9142040.

[22] Puput Dani Prasetyo Adi and Akio Kitagawa, "A Study of LoRa Performance in Monitoring of Patient's SPO2 and Heart Rate based IoT" International Journal of Advanced Computer Science and Applications(IJACSA), 11(2), 2020. doi. 10.14569/IJACSA.2020. 0110232.

[23] Jaber Babaki, et.al, "Dynamic Spreading Factor and Power Allocation of LoRa Networks for Dense IoT Deployments", Conference: 2020 IEEE 31st Annual International Symposium on Personal, Indoor and Mobile Radio Communications, August 2020, DOI: 10.1109/PIMRC48278.2020.9217283.

[24] Puput Dani Prasetyo Adi and Akio Kitagawa, "Performance Evaluation WPAN of RN-42 Bluetooth based (802.15.1) for Sending the MultiSensor LM35 Data Temperature and RaspBerry Pi 3 Model B for the Database and Internet Gateway" International Journal of Advanced Computer Science and Applications(ijacsa), 9(12), 2018. http://dx.doi.org/10.14569/IJACSA.2018.091285.

[25] Muzaiyanah Hidayab, Abdul H Ali, Khairul Bariah Abas Azmi, "Wifi signal propagation at $2.4 \mathrm{GHz}$, January 2010, Conference: Microwave Conference, 2009. APMC 2009. Asia Pacific, DOI: 10.1109/APMC.2009.5384182.

[26] Petrus Kerowe Goran, Eka Setia Nugraha, "Asymmetric-Slit Method on WiFi Antenna with $2.4 \mathrm{GHz}$ and $5 \mathrm{GHz}$ Frequency", September 2020IJITEE (International Journal of Information Technology and Electrical Engineering) 4(2):53, DOI: 10.22146/ijitee.55811.

[27] Mohamed Ibrahim Alhajri, "2.4 GHZ Indoor Channel Measurement", Project: Machine Learning for Contemporary Communication Systems: Methods \& Applications, November 2018, DOI: 10.21227/ggh1-6j32.

[28] Muhammad Niswar., et.al, "Performance evaluation of ZigBee-based wireless sensor network for monitoring patients' pulse status", Conference: Information Technology and Electrical Engineering (ICITEE), 2013 International, DOI: 10.1109/ICITEED.2013.6676255, Oct 2013. 